\title{
INTRODUCING AN ENDOPHYTE FOR CONTROLLING TOMATO EARLY BLIGHT DISEASE
}

\author{
Arab, Y. A.*; Tomader G. Abd-El-Rahman**and Nour-jehan \\ M. M. Eisa** \\ * Botany Dept.., Fac. Agric., Al-Azhar Univ., Cairo, Egypt. \\ ** Plant Pathol. Inst., Agricultural Research Center, Giza , Egypt.
}

\begin{abstract}
Diseased tomato samples showed typical symptoms of the early blight disease were collected from four Egyptian governorates, i.e. Sharkia, Kalubia, Gharbia and Ismailia. All Alternaria solani isolates affect Peto 86 tomato cultivar. Ismailia was the most aggressive isolet. Three Bacillus subtilis isolets (were isolated from planosphere of tomato leaves) and tow Trichoderma viride isolates (were isolated from rhizosphere) inhibited $A$. solani growth with different levels. The most aggressive $B$. subtilis isolate was chosen as a tool to induce disease resistance for tomato seedlings. The application of Bacillus subtilis on tomato seeds achieved a profuse proliferation of endophytically colonized seedlings, tomato plants were then challenged with $A$. solani suspension. The av. hight of endophytically colonized plants increased from $38 \mathrm{~cm}$ for the check plants to $57 \mathrm{~cm}$ for the treated ones. After 45 days keeping under greenhouse conditions, the endophytically colonized and challenged tomato plants exhibited a significant reduction in early blight severity $(7 \%$ compared with $19 \%$ for check plants). The endophytic bacteria was recovered from treated tomato seedlings, indicating that the endophytic $B$. subtilis has the potential to move systemically throughout the plant tissues.

Keywords: Bacillus subtilis, endophyte, tomato early blight, Alternaria solani, disease resistance inducing.
\end{abstract}

\section{INTRODUCTION}

Tomato (Lycopersicon esculentum) is one of the most important vegetable crops in Egypt, and in other countries. The plants are subjected to attack by several diseases that cause great losses for yield production. Early blight caused by Alternaria solani (Ell.\& Mart.) is one of the most serious diseases of all tomato diseases in Egypt (El-Saman,1986).

Recent researches reported that endophytes (microorganisms inhabit plants without causing visible disease symptoms) may exudate chemicals inhibit the growth of causal organisms, including harmful insects and mammalian herbivorus (Carroll, 1998 and Azevedo, 2000), produce some plant-growth-promoters (Varma et al., 1999 and Adeline et al., 2008) and induce plant resistance against different pathogens (Redman et al.,1999, Narisawa et al.,2000, Arnold et al., 2003 and Henson et al., 2007). There is always a degree of antagonistic balance between endophytes and their plant hosts (Schulz, Barbara and Christina Boyle, 2005) except when the host is under stress conditions, so, endophytes appear to be associated with initial degradation of the plant tissues followed by senescence (Amico, Margherita et al., 2007). 
Arab, Y. A. et al.

Many successful trials were carried out on tomato plants including artificially introducing antagonistic endophytes to induce plant disease resistance, i.e. Acremonium sp. against Fusarium wilt of tomato (Brgmann and Schonbeck, 1992 and Grunewaldt-Stoecker et al., 1998), a nonpathogenic strain of Colletotrichum sp. against tomato anthracnose (Redman et al., 2002), Bacillus against tomato wilt (Algam, Soad et al., 2005), Actinomycetes against Ralostonia solanacearum (Tan et al., 2006) and nonpathogenic strain of Fusarium solani against tomato soil pathogens (Kavroulakis et al., 2007). Grunewaldt-Stoecker and Alten (2003) stated that the injected endophyte must be permanently present within plant tissues before pathogenic infection, to maintain successful systemic disease protection.

In the present study we isolated some organisms from leaves and root tissues of tomato plants to identify the possibility for being biocontrol agents against Alternaria solani and to induce disease resistance against tomato early blight disease, as one of the most effective methods in the integrated best management program.

\section{MATERIALS AND METHODS}

Diseased tomato samples showed the typical symptoms of the early blight disease were collected from four Egyptian governorates, i.e. Sharkia, Kalubia, Gharbia and Ismailia. Two fields from each governorate were chosen. The samples were transmitted to the laboratory for isolation and identification. Isolation, purification using single spore technique, and identification was carried out Ellis, 1971.

\section{Pathogenicity test :}

Pathogenicity test was carried out in the greenhouse using the identified isolates as Alternaria solani. The inoculum was prepared by growing the pathogenic fungus on Czapek's liquid medium for 10 days. Tomato seeds of the susceptible cultivar Peto 86 were obtained from the Agric. Res. Center, Giza. Seeds were planted in a shallow for 1.5 month, then seedlings were transplanted into green house. Inoculation was carried out by spraying the inoculum of $A$. solani isolets $\left(5 \times 10^{3}\right.$ conidia/ml) on plant leaves. Plants were sprayed with distilled water were used as check. Disease assessment was carried out 10 days after inoculation according to Christ (1991) as follows:

$0.1=$ a few circular lesions $(1-2 \mathrm{~mm}$ ).

$0.5=$ up to $5 \%$ of the leaf area spotted.

$0.75=$ above $5 \%$, but below $10 \%$ of leaf area spotted.

$1=$ above $10 \%$, but below $25 \%$ of leaf area spotted.

$2=$ above $25 \%$, but below $50 \%$ of leaf area spotted.

$3=$ above $50 \%$, but below $75 \%$ of leaf area spotted.

$4=$ above $75 \%$ to $100 \%$ of leaf area spotted.

Mean disease severity for a plant was calculated as the mean of disease severity values of all leaves of that plant. 
Isolation and identification of antagonistic organisms:

Bacillus subtilis was isolated from planosphere of tomato leaves and identified according to Harrigan and McCance (1976), while, Trichoderma viride was isolated from rhizosphere of tomato roots and identified according to Rifai (1969).

\section{The antagonistic tests:}

The antagonistic effect of both organisms above was studied against $A$. solani in vitro. Regarding Bacillus isolates, The method described by Abo ElNaga, Heidi , 2006 was applied as follows: Plates of PDA medium was inoculated with two equal discs of $A$. solani. The antagonistic bacterium ( $B$. subtilis) was streaked at the centre of each plate by a loop loaded with $48 \mathrm{hr}$ old bacterial culture grown at $27^{\circ} \mathrm{C}$ on nutrient broth. Four plates were used for each combination. Antagonistic effect was determined by measuring zones between the antagonistic bacteria and the tested fungus. Petri dishes with $A$. solani discs only were served as control check.

However, mycelial discs (5 $\mathrm{mm}$ in diameter) were cut from7-day-old PDA cultures of $A$. solani and T.viride, two discs (one of each fungus) were transmitted into each experimental dish (containing PDA media), and facing each other with $40 \mathrm{~mm}$ distance between them (one disc in each side). Four plates per each combination were incubated at $25 \pm 2^{\circ} \mathrm{C}$. Dishs containing PDA medium and discs of $A$. solani only were used as control check. Inhibition zone diameters (in $\mathrm{mm}$ ) were determined after 7 days of incubation period (Sabet and Khan,1969).

\section{Endophytically colonization of tomato seeds :}

Pots (50 cm in diameter) were filled with sterilized sandy-clay soil. At the same day of planting, surface sterilized tomato seeds of the susceptible cultivar, Peto 86, were soaked five hours before planting in Petri-dish containing a 3-days-old culture of Bacillus subtilis (108-109 cfu/ml) and was grown in liquid tryptic soybean medium (Anonymous., 2003). [One liter of the medium contains: $17 \mathrm{~g}$ Tryptone, $3 \mathrm{~g}$ Soytone (enzymatic, digest of soybean meal), $2.5 \mathrm{~g}$ Dextrose, $5 \mathrm{~g}$ Sodium Chloride and $2.5 \mathrm{~g} \mathrm{~K} \mathrm{~K}_{2} \mathrm{HPO}_{4}$ ]. Ten treated seeds were planted in each pot to be artificially inoculated with Alternaria solani. Surface sterilized un-soaked seeds were served as a control check. Five pots were used for each treatment, Five pots were cultivated with treated seeds also prepared to study the bacterial effect on tomato growth. Tomato seedlings were sprayed by spore suspension of $A$. solani $\left(5 \times 10^{3}\right.$ conidia/ml) after five rows of true leave stage.

Assessment of disease severity of tomato early blight was estimated after 7 days of inoculation as described by (El-Saman,1986). The recovery of Bacillus subtilis was carried out. All the seedlings were left under greenhouse conditions. Plant height was recorded at 30 and 45 days after sowing. The experiment was implemented for the tow successive seasons (2007 and 2008).

\section{Statistical analysis:}

The obtained results were statistically analyzed according to Gomez and Gomez ,1984. 


\section{RESULTES AND DISCUSSION}

Isolatoin and identification of the causal organism :

Tomato plants showing leathery, dark brown, necrotic lesions on the older leaves, which develop concentric black rings due to the conidia formation, were taken to isolate the causal pathogen from the affecfed leaves. The obtained cultures were identified according to Ellis ( 1971) as Alternaria solani fungus.

Pathogenicity test :

Data present in table (1) indicate that all the tested isolates affected tomato plants. Ismailia isolate was the most aggressive one flowed by Kalubia isolate, while Sharkia and Gharbia isolates were less effective, this may be due to the environmental conditions in Ismailia and Kalubia that was more favorable to the prevalent isolate of $A$. solani, and to the development of early blight disease. Similar result was obtained in the investigation of (Rashed, 1999) on the same tomato cultivar.

Table (1) : Effect of different isolates of Alternaria solani on early blight disease severity of tomato plants cv. Peto 86.

\begin{tabular}{|c|c|c|}
\hline $\begin{array}{l}\text { Governorate of } \\
\text { isolate }\end{array}$ & Location & Disease severity \\
\hline \multirow[t]{2}{*}{ Gharbia } & Kafr El-Zayat & 7.5 \\
\hline & Mahala & 7.0 \\
\hline \multirow[t]{2}{*}{ Ismailia } & Ismailia & 23.2 \\
\hline & Kasaseen & 20.4 \\
\hline \multirow[t]{2}{*}{ Kalubia } & Banha & 16.5 \\
\hline & Kanater El-Khyria & 14.3 \\
\hline \multirow[t]{2}{*}{ Sharkia } & Zagazig & 10.5 \\
\hline & Hehia & 9.5 \\
\hline LSD at $5 \%$ & & 2.9 \\
\hline
\end{tabular}

Isolation and identification of antagonistic organisms :

Two Trichoderma viride isolates were isolated from rhizosphere of tomato roots and three Bacillus subtilis isolates were isolated from planosphere of tomato leaves. The antagonistic tests which carried out in vitro using discs on PDA media indicated that all the tested isolates of $B$. subtilis or T. viride inhibited the mycelial growth of Alternaria solani but the bacterium was more antagonistic than Trichoderma.

Table ( 2 ) : Effect of the antagonistic organisms on A. solani growth after 7days of incubation.

\begin{tabular}{|l|l|c|}
\hline \multicolumn{1}{|c|}{ Treatments } & \multicolumn{1}{|c|}{ Location } & $\begin{array}{c}\text { Av. of inhibition zone after } \\
\mathbf{7} \text { days ( in } \mathbf{~ m m . )}\end{array}$ \\
\hline \multirow{3}{*}{ Bacillus subtilis } & Ismailia & 21.0 \\
\cline { 2 - 3 } & Kasaseen & 17.5 \\
\cline { 2 - 3 } & Banha & 19.0 \\
\hline Trichoderma viride & Kasaseen & 11.0 \\
\cline { 2 - 3 } & Mahala & 8.5 \\
\hline Check $($ A. solani alone $)$ & smailia & 0.0 \\
\hline LSD at 5\% & & 5.5 \\
\hline
\end{tabular}


The three Bacillus subtilis isolates exhibited inhibition effect with different degrees against Alternaria solani growth on PDA medium. The most aggressive $B$. subtilis isolate (Ismailia) was chosen as a tool to induce disease resistance in tissues of tomato seedlings. This effect agreed with the effect of using $B$. pumilus to inhibit mycelial growth of many other fungi (Bollone and Pelaso, 2003 and Zhang et al., 2007 )

\section{Endophytically colonization of tomato seedlings :} effects:

The application of Bacillus subtilis on tomato seeds achieved many

-No significant damage was noticed on endophytically colonized seedlings. This is in agreement with the meaning of the term" endophyte "of Carroll, 1998.

-There was a profuse proliferation of endophytically colonized plants. The hight of endophytically colonized plants increased from $38 \mathrm{~cm}$ for the check plants to $57 \mathrm{~cm}$. for the treated plants. So, there was a remarkable enhancement to the growth of the endophytically colonized tomato plants. This result is in harmony with the findings of Verma, 1999 and Redman et al., 2002.

-Seven days after infection with Alternaria solani, the endophytically colonized and challenged tomato seedlings - exhibited a significant reduction in early blight disease under greenhouse conditions.

Table (3): Blighted tomato seedlings \% and plant hight/seedling (in $\mathrm{cm}$.) after Bacillus application inside plant tissues, seasons 2007 and 2008.

\begin{tabular}{|c|c|c|c|c|c|c|}
\hline \multirow{3}{*}{ Treatments } & \multicolumn{3}{|c|}{ season 2007} & \multicolumn{3}{|c|}{ season 2008} \\
\hline & \multirow{2}{*}{$\begin{array}{c}\text { Blighted } \\
\text { seedlings \% }\end{array}$} & \multicolumn{2}{|c|}{$\begin{array}{l}\text { Plant hight / seedling } \\
\text { ( in } \mathrm{cm} \text {. ) after }\end{array}$} & \multirow{2}{*}{$\begin{array}{c}\text { Blighted } \\
\text { seedlings \% }\end{array}$} & \multicolumn{2}{|c|}{$\begin{array}{l}\text { Plant hight / seedling } \\
\text { ( in cm. ) after }\end{array}$} \\
\hline & & 30 days & 45 days & & 30 days & 45 days \\
\hline $\begin{array}{l}\text { Protected } \\
\text { seedlings }\end{array}$ & 7.0 & 35.0 & 57.0 & 7.9 & 33.0 & 55.5 \\
\hline Control I* & 19.0 & 23.0 & 38.0 & 20.3 & 21.5 & 36.5 \\
\hline Control II ${ }^{\star \star}$ & 2.6 & 30.0 & 54.0 & 2.2 & 28.3 & 51.2 \\
\hline LSD at $5 \%$ & 1.5 & 5.3 & 4.2 & 1.02 & 3.12 & 4.0 \\
\hline
\end{tabular}

* Control I = Free endophye and challenged seedlings.

** Control II = Endophytically colonized and not challenged seedlings.

This result agreed with those reported by Georgy, 1977, Podile, 1993 and Abo El-Naga, Heidi, 2006. They used Bacillus subtilis to induce resistance against the pathogens of onion white-rot, peanut root-rot and sugar beet damping-off , respectively.

To discover the mechanisms behind inducing systemic effects of delayed and reduced tomato early blight symptoms and reduce pathogen spread by using Bacillus spp., Katz and Demain, 1977 stated that Bacillus species produce 167 biological compounds active against pathogenic bacteria, fungi, protozoa and viruses. Several peptide antifungal compounds synthesized by Bacillus spp. are active against filamentous fungi and yeast such as Mycocerein, Pumiucidin, Rhizocticin, Fungicin $\mathrm{M}_{4}$ and Hcxacne (Wakayama et al., 1984, Karuse et al., 1990, Kugler et al., 1990, Lebbadi et 
al., 1994, Kudryashava et al., 2005). Also, Fiddaman and Rossak, 1993 reported that Bacillus subtilis produces some antifungal volatiles.

The endophytic bacteria was recovered from the imerged treated seeds after tow weeks from application, indicating that the endophytic $B$. subtilis has the potential to move throughout the plant tissues. This result is in agreement with the findings of Grunewaldt-Stoecker et al., 1998 who stated that endophytic organisms are easily detected inside the target plant tissues in the second week after injection.

\section{REFERENCES}

Abo El-Naga, Heidi, 2006. Bacillus subtilis as a biocontrol agent for controlling sugar beet damping-off disease. Egypt. J. Phytopathol., 34(1):51-59.

Adeline, S.Y., S. Meon, J. Kadir, S.Radu and G. Singh, 2008. Endophytic microorganisms as potential growth promoteterss of banana. Biocontrol, 53 (3) : 541-553.

Algam, Soad A., X.G. Lin and J. Coosemans, 2005. Delivery methods for introducing endophytic Bacillus subtilis into tomato and their effect on growth promotion and suppression of tomato wilt. Plant Pathol. J., 4 (1): 6974.

Amico, Margherita D., S.W. Frisullo and M. Cirulli, 2007. Endophytic fungi occurring in fennel, lettuce, chicory and celery commercial crops in Southern Italy. -Micological Research, 112 : 100-107.

Anonymous, 2003. Tryptic soy agar medium. International Harmonisation Pharmeuropa, 15 (3):563-573.

Arnold, A. Elizabeth, L.C. Mejia, D. Kyllo, E.I. Rojas, Zuleyka Maynard, Nancy Robbins and E.A. Herre, 2003. Fungal endophytes limit pathogen damage in tropical tree. Proc. Nat. Acad. Sc., 100 : 1564915654.

Azevedo,T.M.,2000. Endophytic microorganisms :A review on insect control and recent advances to tropical plants. E. J. B. Electronic J. of Biotechnology,3 (1): 40-60.

Bargmann, C. and F. Schonbeck, 1992. Acremonium kiliens as inducer of resistance to wilt disease on tomatoes. J. Plant Diseases and Protection, 99 : 266-272.

Bollone, E.J. and R.W.Pelaso, 2003. Production by Bacillus pumilus of an antifungal compound that is active against Mucoraceae and Aspergillus species. J. Med. Microbiol., 52:69-74.

Carroll, G.C., 1998. Fungal endophytes in stems and leaves from latent pathogen to mutulistic Symbiont. Ecol., $69: 2-9$.

Christ , B.J. ,1991. Effect of disease assessment method on Ranking potato cultivars for resistance to early blight. Plant Dis., $4: 353$.

Ellis, M. B., 1971.Dematiaceous hyphomycetes. Kew, Surrey, Commonwealth Mycological Institute, $608 \mathrm{pp}$.

El-Saman,M.G.,1986.Studies on early blight disease of tomato. M. Sc. Thesis, Fac. of Agric., AinShams Univ., 85 pp.

Fiddaman, P.J. and S. Rossal,1993. The production of antifungal volatiles by Bacillus subtilis. J. Appl. Bacteriol., 74 :119-126. 
Georgy, N.I.1977. Studies on the fungus Sclerotium cipivorum causing white rot of onion and its control. Ph.D.Thesis, Fac. of Agric., AinShams Univ., 90 pp.

Gomez, K.A. and Gomez, A.A. 1984. Statistical Procedures for Agricultural Research. John Wiley \& Sons, Inc. New York, U.S.A. 680 pp.

Grunewaldt-Stoecker,G. and H.V. Alten,2003. Plant health of Acremonium root endophytes compared to those of arbuscular mycorrhiza. Developments in Plant and Soil Sciences, $101: 445-454$.

Grunewaldt-Stoecker, G. , T. Kraska and E. Maiss, 1998. PCR- based detection of soil-borne and root-colonizing Acremonium endophytes inducing Fusarium-wilt resistance in linseed and tomato plants. Mittlg. Bundesanstalt, $357: 260$.

Harrigan, W.F. and M. McCance ,1976. Laboratory Methods in Microbiology, Acad. Press, New York, p. 362.

Henson, J.M., Kathy B. Sheehan , Russell J. Rodriguez and R. S. Redman, 2007. Use of endophytic fungi to treat plants. United States Patent., 7232565.

Karuse, N., O. Tenyo, S. Kobarus, H. Kamei, T. Miyaki, M. Konishi and T. Oki, 1990. Pumilucidin, a complex of new antiviral antibiotics. Production, isolation, chemical properties, structure and biological activity. J. Antibiot.,43:267-280.

Katz, E. and A.L.Demain, , 1977. The peptide antibiotics of Bacillus. Chemistry, biogenesis and possible functions. Bacteriol. Rev., 40 : 449474.

Kavroulakis, N., S. Ntougias, G.I. Zervakis, C.Ehaliotis, K. Haralamoidis and K.K. Papadopoluou, 2007. Role of ethylene in the protection of tomato plants against soil -borne fungal pathogens conferred by an endophytic Fusarium solani strain . J. Exoermental Botany , 58 : 38533864.

Kudryashava, E., N. Vinokurova and E. Ariskina , 2005. Bacillus subtilis and phenotypically similar producing Hcxacne antibiotic. Appl. Biochem. Microbiol., 41 :486-489.

Kugler, M., W. Loeffler, C. Rapp, A.Kein, A.G.Jung, 1990.Rhizocticin A, an antifungal phosphono-oligopeptide of Bacillus subtilis. Arch. Microbiol., $153: 267-281$.

Narisawa, K., T. Ohki and T. Hushiba , 2000. Suppression of clubroot and Verticillium yellows in Chinese cabbage in the field by the root endophytic fungus, Heteroconium chaetospira. Plant Pathol., 49 : 141146.

Podile,A.R., 1993. Induction of host-plant resistance in peanut against soil borne pathogens by Bacillus subtilis. $6^{\text {th }}$ International Cong. of Plant Pathol.

Rashed, A.A., 1999. Pathological and physiological studies on tomato early blight and its control in Egypt. M. Sc.Thesis, Fac. Agric. , Al Azhar Univ., $89 \mathrm{pp}$. 
Redman, R. S., M. R. Rossinck, S. Maher, Q. C. Andrews,W. L. Schneider and R. J. Rodriguez, 2002. Field performance of cucurbit and tomato plants infected with non-pathogenic mutant of Colletotrichum magna .Symbiosis, $32: 55-70$.

Redman, R.S. , S. Freeman, D.DR. Clifton, J. Morrel, G. Brown and R.J. Rodriguez, 1999. Biochemical analysis of plant protection afforded by a nonpathogenic endophytic mutant of Colletotrichum magna. Plant Physiol., 119 : 795-804.

Rifai, M. A. , 1969. A revision of the genus Trichoderma. Mycol .,116:1 -56.

Sabet, K.A. and I.D. Khan, 1969. Interaction of cotton root- infecting fungi. Cott. Gr. Rev., 46 : 201-222.

Schulz, Barbara and Christin Boyle, 2005. The endophytic continuum. Mycological Research of Cambridge Univ., 109 ( 9 ) :661-686.

Tan, H. M., L. X. Cao, Z. F. He, G. J. Su, B. Lin, S. N. Zhou, 2006. Isolation of endophytic actinomycetes from different cultivars of tomato and their activities against Ralstonia solanacearum in vitro. World J. Microbiol. Biotechnol., 22 (2): 1275-1280.

Verma, A., S. Verma, N. Sahay, B. Butehorn and P. Franken, 1999. Piriformospora indica, a cultivable plant- growth- promoting root endophyte. App. Environ. Microbiol., 65 : 2741-2744.

Wakayama, S. , F.Ishikawa, K.Oishi, 1984. Mycocerein, a novel antifungal peptide antibiotic produced by Bacillus cereus, antimicrob. Agents Chemother., 26 : 939-940.

Zhang, T., Z. Q. Shi, L. B. Hu, L.g.Gheng and F. Wang, 2007. Antifungal compounds from Bacillus subtilis inhibiting the growth of Aspergillus flavus. World J. Microbiol. And Biotechnol., 783-788.

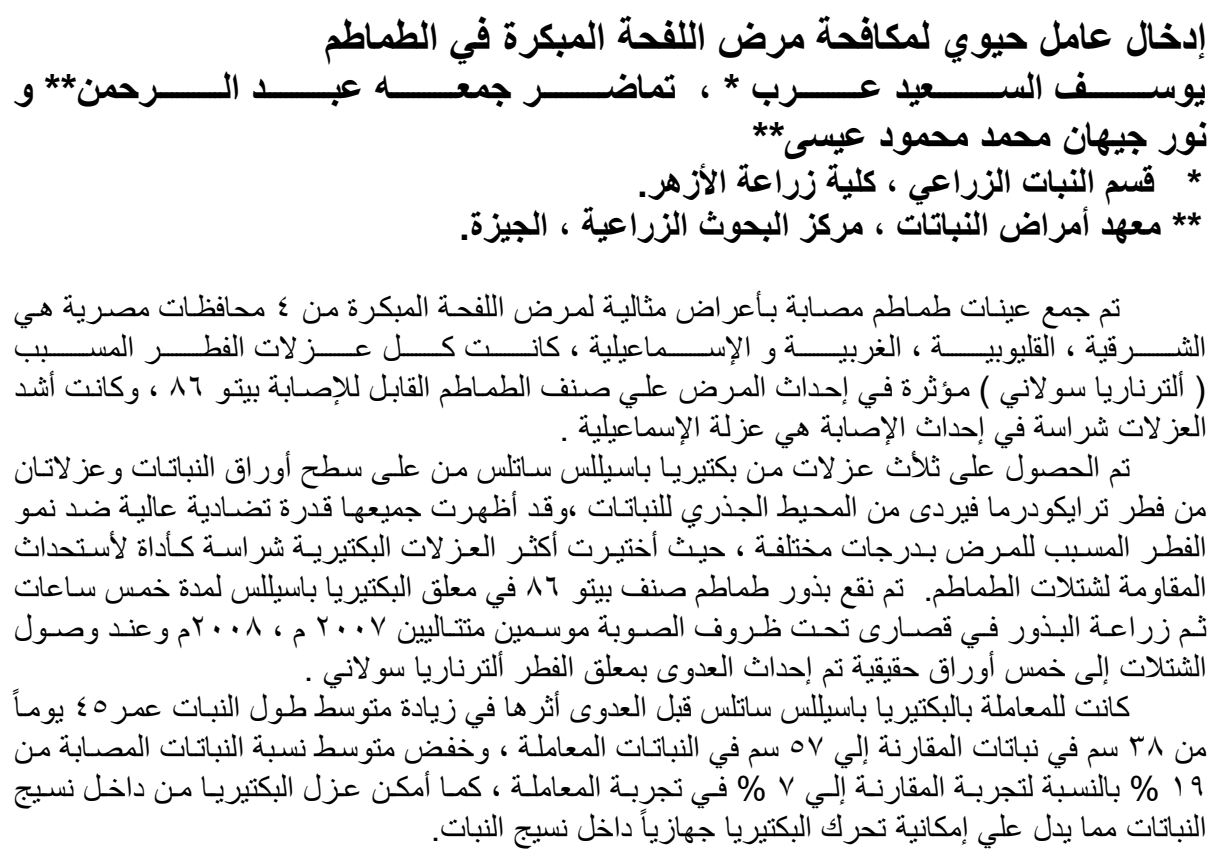


J. Agric. Sci. Mansoura Univ., 34 (6), June, 2009

6843 